\title{
A Case Study of Adopting European Experience of Office Hours to Improve Off-class Instructor- student Interaction in Private Universities in China
}

\author{
Shaoying $\mathrm{Wu}$ \\ University of Sanya, \#191 Yinbin Ave, Sanya, Hainan Province 572022, P.R.China
}

\begin{abstract}
To integrate with international standards, the University of Sanya explores European experiences in teaching and management. In 2016, the university promoted a campus-wide office-hour policy to improve studentteacher communication after class. However, after four years of implementation, most teachers believe such a policy failed to achieve the goal. Therefore, the author delivers questionnaires and interviews to students and teachers from selected business majors. This paper finds that office hour was an inferior way to communicate as in China students are allowed to have teachers' personal contact information. And students learning behavior is key to off-class communication. Moreover, the working environment affects teachers attitudes towards office hour. Office hour is a small case but can be inspiring to the future adoption of foreign experience in education as preinvestigation and localization do matter.
\end{abstract}

\section{Introduction}

Private universities in China used to compete against the public ones in the earlier 20th century. However, these private universities encountered enormous challenges and difficulties due to the social and historical change and complex international background. Gradually, private-owned universities withdrew from the stage of China's higher education and went back on stage after the late 1970s when China announced the economic reform and open-up policy. For the past forty years, private universities developed from scratch. To improve the overall educational quality as well as to survive the pressure from the public universities, private universities in China walk out of the border and actively absorb the experiences overseas. Some experiences benefit the development of private universities, while others become a promotional stunt for the institution. Being one of the top five private universities in China, the University of Sanya can not avoid such a trend.

To integrate with international standards, the University of Sanya studies European and American experiences in teaching and management and explores education reforms on campus.

One of the experiences learned from Europe is requiring the individual instructor to have on-site office hours, to increase student performance and engagement by faculty-student interaction. According to such a campus-wide proposal, a teacher must have at least $1 / 3$ of one's off-class hours in the office. And each school is required to set a corresponding policy 
to guarantee teachers are in their office. Therefore, teachers are facing attendance checks during their office hours and an absence with no will affect the teacher's annual evaluation as well as the school's annual assessment held by the university.

Chickering and Garmson first highlighted that frequent instructor-student interaction is key to student motivation and involvement[1]. Following empirical studies substantiated their insights. Moreover, quality interaction with instructors improves students' confidence in academic performance and aspirations for further study [2,3]. Office hours realize such interaction. However, it is not common to have mandatory office hours in China's universities, and not many studies in China focus on such a field. Hong and Hu believe that office hours applied in Nanchang University promote interaction between teachers and students and stimulate students' learning motivation and effectiveness [4], however with no data support analysis. Nevertheless, researchers are unsatisfied with students' involvement in office hours as the office hours become a rather lonely time for the instructors [5]. To explain students' under-utilization of office hours, studies delve into the factors that affect students' attendance of office hours. Generally speaking, instructors' influence and approachability to students and ease-of-access issues affect students' attendance $[6,7,8,9]$. Researches also notice that instant messaging and Internet-based technology is used to conduct office hours. However, while some scholars believe the instructor-student interaction benefits from information technology while some others not $[5,10]$.

China has a rapid development in communication applications, such as WeChat and QQ, which are widely used in daily life. Therefore, under the reality in China, whether on-site office hours are the key to instructor-student remains worthy of discussion.

\section{Method}

To evaluate the role office hours played in instructor-student interaction in business school from the University of Sanya, the author utilizes questionnaires and unstructured interviews to capture data from both students and teachers.

\section{Procedure}

This study collected data from instructors and students from business school, S. Students majoring in $\mathrm{Y}$ from School M also participated in the students' survey for comparison. Major $\mathrm{Y}$ is the only one that has similar courses as Major X. Moreover, only junior students participated in the survey. According to Cotten and Wilson [11], the students' familiarity with the institution and its norms affect the students' willingness and frequency to interact with teachers; yet such familiarity takes time. Considering that the freshmen and sophomores may not familiar with the university life and office hour and seniors are off-campus for the internship, only juniors answers questionnaires.

After the literature review on factors affecting the office hours use, the author designed a short survey to understand teachers' overall perception of the office hours performance. The survey contains one yes/no question of teacher's overseas study experience. The rest are scale questions, covering topics like teacher's impression of office hours, the frequency of different off-class interacting approaches, the preferred topics raised in students' visit, and current dilemmas faced by teachers reg office-hours. Then the author delivers an unstructured interview to teachers, delving into the factors behind teachers' perception.

Based on the information collected from teachers' surveys and interviews, the author designed a survey to students on their office hours use, their learning behaviors, and their evaluation of the instructor-student interaction experience. To ensure the reliability of the questionnaire, all questionnaires are anonymous. 


\section{Participates}

School S has eight full-time instructors engaged in office-hours. All of them participated in the teacher's survey and interview. About $76 \%$ of the juniors majoring in $X$ and $64 \%$ majoring in Y participated in the students' survey. The author collected 180 valid students' responses. Of 32 students' responses from Major X, 50\% self-identified as female and 50\% as male; of 148 students' responses from Major Y, $60 \%$ self-identified as female and $40 \%$ as male. All matches the gender composition of each major (Table 1).

Table 1. Students' Gender Composition for the Survey Compared to Juniors in Total

\begin{tabular}{ccccc}
\hline & \multicolumn{3}{c}{ Major $\mathrm{X}$} & Major Y \\
\hline Survey(M:F) & $1:$ & 1 & $1: 1.64$ \\
Juniors in total(M:F) & & $1:$ & 1 & $1: 1.75$ \\
& & & & \\
\hline
\end{tabular}

Instead of the traditional five-point Likert scale, six-point scales are applied to evaluate most questions on the survey. The higher the score is, the higher the agreement with the statement is. Among them, scores 1-3 are regarded as a negative attitude towards the statement, while scores 4-6 a positive feedback.

\section{Results and Discussion}

Both teachers and students expressed positive attitudes towards off-class instructor-student interaction; however, teachers display negative attitudes towards the effect of office hours on interaction, and students preferred to interact by Wechat or QQ rather than on-site office hours.

Survey asks instructors to rate the overall performance of instructor-student interaction. The average score is 4.8 out of 6 . The survey also asks them to rate the contribution of office hours to office hours. The average score is 2.4 out of 6 . Half of the instructors used to study overseas and visited their teachers during office hours. They leave an average of 4.8 points for the overseas office-hour experience, but 2.7 for the one carried in the University of Sanya. According to the interviews, all instructors are confident about their approachability to students as well as the frequency of their off-class interaction with students. Moreover, they point out that at most $10 \%$ of the interaction happens during the scheduled office hour. What confuses teachers is whether the tutoring out of the office hours is recognized by the university, considering that the university is rather strict on teachers' attendance of office hours. All instructors interviewed had the experience of receiving students' messages during non-working hours, even after $10 \mathrm{pm}$, and they replied once they noticed it.

Students' responses display positive attitudes towards instructor-student interaction. However, students of Major X show higher satisfaction with an average score of 4.75 out of 6 , compared with 4.43 given by students of Major Y (Table 2). Furthermore, around $20 \%$ of the students surveyed have never talked face-to-face with any instructor for three years in the university. The survey asks the rest $80 \%$ of the students to rate the frequency of their interaction with teachers during teachers' scheduled office hours. About $65 \%$ of them, who have talked to instructors off-class, are rarely happened during scheduled office hours. Additionally, the students from major X have a higher frequency of office hours usage (Table 2). The result matches with instructors' feedback that students rarely visit teachers during their scheduled hours. 
Table 2. Students' Evaluation on the Instructor-Student Interaction and Office Hours Use

\begin{tabular}{|c|c|c|c|c|c|c|c|c|}
\hline & \multicolumn{4}{|c|}{ Maior X } & \multicolumn{4}{|c|}{ Maior Y } \\
\hline & Ave. & SD & $\begin{array}{l}\text { Percenta } \\
\text { ge of 1-3 } \\
\text { score }\end{array}$ & $\begin{array}{l}\text { Percentage of } \\
4-6 \text { score }\end{array}$ & Ave. & SD & $\begin{array}{l}\text { Percenta } \\
\text { ge of } 1-3 \\
\text { score }\end{array}$ & $\begin{array}{l}\text { Percentage of } \\
4-6 \text { score }\end{array}$ \\
\hline \multicolumn{9}{|l|}{ Overall } \\
\hline & 4.75 & 1.08 & $9 \%$ & $91 \%$ & 4.43 & 1.13 & $21 \%$ & $79 \%$ \\
\hline Office & & & & & & & & \\
\hline hours use & 2.61 & 1.55 & $77 \%$ & $23 \%$ & 3.06 & 1.57 & $62 \%$ & $38 \%$ \\
\hline
\end{tabular}

Moreover, according to the survey, the author finds both students and teachers agree that teachers are more active than the students in instructor-student action. And students interact with instructors from their school more often than with the ones from other schools.

To examine the under-utilization of office hours, the author asks instructors their understanding of the factors that led to such phenomenon. Their responses show that students' study motivation/initiative as well as preference for virtual communication tools are the top factors, which however are beyond instructors' control.

The survey asks a series of self-evaluation questions on students' learning behavior[12], both in-class and off-class (Table 3). Students are more active in teamwork or group discussion than individual presentations and question and answer. It matches the universal impression on general Chinese students, hardworking but self-constrained. Regarding offclass behaviors, the majority of students manage to submit homework on time, mainly because homework constitutes the final score of the subject. However, students are less active in off-class discussion, library resource utilization, and preview and review, which can hardly be monitored and scored by instructors. Learning habits and behaviors form in a long time, which affects students' previous performance as well. The students with inferior high school academic performance enroll in secondary universities, like the University of Sanya. Therefore, the survey asks students to recall their performance in senior high school. According to the results, $5 \%$ of the students ranked top $10 \%, 21 \%$ of them $11 \%-25 \%, 32 \%$ of them $26 \%-50 \%, 30 \%$ of them 50\%-75\%. Moreover, major X has more students with poor academic performance in high school than Major Y, as 53\% of the students from major X used to be the last $50 \%$ ones in their high school.

Table 3. Students' Response on Learning Behavior

\begin{tabular}{|c|c|c|c|c|c|c|}
\hline \multicolumn{3}{|c|}{ Major $\mathrm{X}$} & \multicolumn{4}{|c|}{ Major Y } \\
\hline Average In-class & Score & $\begin{array}{c}\text { Percentage of } \\
1-3 \text { score }\end{array}$ & $\begin{array}{l}\text { Percenta } \\
\text { ge of 4-6 } \\
\text { score }\end{array}$ & $\begin{array}{c}\text { Average } \\
\text { Score }\end{array}$ & $\begin{array}{l}\text { Percentage of } \\
1-3 \text { score }\end{array}$ & $\begin{array}{l}\text { Percentage } \\
\text { of } 4-6 \text { score }\end{array}$ \\
\hline $\begin{array}{c}\text { Active in } \\
\text { teamwork/group } \\
\text { discussion }\end{array}$ & 4.25 & $31 \%$ & $69 \%$ & 3.65 & $46 \%$ & $54 \%$ \\
\hline $\begin{array}{l}\text { Active in individual } \\
\text { presentation }\end{array}$ & 3.38 & $59 \%$ & $41 \%$ & 3.22 & $61 \%$ & $39 \%$ \\
\hline $\begin{array}{l}\text { Raise and answer } \\
\text { questions }\end{array}$ & 3.13 & $66 \%$ & $34 \%$ & 3.52 & $55 \%$ & $45 \%$ \\
\hline
\end{tabular}


Continuation of Table 3

\begin{tabular}{ccccccc}
\hline $\begin{array}{c}\text { Submit homework on } \\
\text { time }\end{array}$ & 4.66 & $13 \%$ & $88 \%$ & 5.11 & $14 \%$ & $86 \%$ \\
$\begin{array}{c}\text { Discuss with } \\
\text { classmates }\end{array}$ & 3.50 & $50 \%$ & $50 \%$ & 3.76 & $45 \%$ & $55 \%$ \\
$\begin{array}{c}\text { Discuss with } \\
\text { teachers Use library }\end{array}$ & 3.31 & $59 \%$ & $41 \%$ & 3.09 & $60 \%$ & $40 \%$ \\
$\begin{array}{c}\text { resources for } \\
\text { further study }\end{array}$ & 3.34 & $63 \%$ & $38 \%$ & 4.25 & $32 \%$ & $68 \%$ \\
Preview and review & 3.19 & $69 \%$ & $31 \%$ & 3.78 & $43 \%$ & $57 \%$
\end{tabular}

Survey also asks students to evaluate their preference for problem-solving methods. The top solution to problems is to find the answer online by themselves. If problems remain unsolved, students prefer to ask classmates or friends for help rather than an instructor. If professional instruction is needed, visiting the teacher during office hours is not the first choice. Both teachers and students select online communication as the most popular method of off-class interaction. The majority of students contact instructors by WeChat or QQ (Table 4). The European culture emphasizes individual privacy; therefore, instructors in European universities rarely leave their personal contact information to students. However, in China, efficiency outweighs privacy. It is common for students to have instructors' personal contact information, including phone numbers and social media accounts. Another difference is that, in Europe, email is popular in business and academia. In China, people exceedingly apply WeChat and QQ in their lives and work. Hence, if students can not receive answers by WeChat or QQ, they tend to raise the question during the class break if necessary. When the above methods failed, students will visit instructors the other time, which may not be in the office hours.

Table 4. Students' Frequencies of Different Communicating Methods

\begin{tabular}{|c|c|c|c|c|c|c|}
\hline \multicolumn{4}{|c|}{ Major X } & \multicolumn{3}{|c|}{ Major Y } \\
\hline & $\begin{array}{r}\text { Average } \\
\text { Score }\end{array}$ & $\begin{array}{l}\text { Percentage } \\
\text { of } 1-3 \text { score }\end{array}$ & $\begin{array}{l}\text { Percentage } \\
\text { of } 4-6 \text { score }\end{array}$ & $\begin{array}{l}\text { Average } \\
\text { Score }\end{array}$ & $\begin{array}{l}\text { Percentage } \\
\text { of } 1-3 \text { score }\end{array}$ & $\begin{array}{l}\text { Percenta } \\
\text { ge of } 4-6 \\
\text { score }\end{array}$ \\
\hline WeChat & 4.45 & $26 \%$ & $74 \%$ & 3.30 & $59 \%$ & $41 \%$ \\
\hline QQ & 3.58 & $52 \%$ & $48 \%$ & 3.45 & $57 \%$ & $43 \%$ \\
\hline Phone Call & 2.29 & $87 \%$ & $13 \%$ & 2.47 & $76 \%$ & $24 \%$ \\
\hline Email & 1.87 & $87 \%$ & $13 \%$ & 2.12 & $85 \%$ & $15 \%$ \\
\hline Letter & 1.39 & $94 \%$ & $6 \%$ & 1.79 & $85 \%$ & $15 \%$ \\
\hline \multicolumn{7}{|l|}{ Face-to-face } \\
\hline conversation & 3.65 & $55 \%$ & $45 \%$ & 3.04 & $61 \%$ & $39 \%$ \\
\hline Others & 2.23 & $84 \%$ & $16 \%$ & 2.39 & $74 \%$ & $26 \%$ \\
\hline
\end{tabular}

Compared with students of Major Y, students of major X use Wechat more often than QQ (Table 4), which coincides with the fact that instructors from Major X use Wechat more 
often than QQ to communicate in academia and student affairs during their working hours. Furthermore, students from Major X have a higher frequency in face-to-face conversation, as Major X has a higher teacher/student ratio and higher convenience. The teacher/student ratios of major X and Major Y are 1/31 and 1/92, respectively. And the instructor offices and most of the students' classroom major X are in the same building, while that of Major Y are in separate buildings. Moreover, working environments affect teachers' office hours experience. In major X, each instructor has the exclusive use of one office room, while seven instructors of Major Y share one big office. As half of the instructors interviewed in Major $\mathrm{X}$ used to work for Major $\mathrm{Y}$, they expressed the importance of having an independent working space.

Based on the case study, office hours contribute not much to instructor-student interaction. Nevertheless, the interaction and student engagement are of greater importance than the office hours policy. Office hours are one of the approaches to achieve such a goal. It is crucial for institutions and teachers to clarify attitudes about the purpose of importing such policy. This study is limited in that it was research on business schools of one university. Even two business majors present differences in many aspects, not to mention differences among schools and between public and private universities. Additionally, it is worth discussing how to localize office hours and make use of virtual tools in interaction. However, this study offers inspiration on the adoption of advanced overseas experience on private universities in China, be cautious on the adaptability and localization do matter.

\section{Conclusion}

1. Chinese instructors have higher approachability because students are accessible to instructors' personal contact information, which breaks the limit of time and location. The most popular approach to communicate with teachers is Wechat and QQ, rather than on-site office hour.

2. Office hours may not reach the goal of improving off-class instructor-student interaction if most students are not making use of office hours. The under-utilization may be caused by students' motivation and their preference in communication methods, which are beyond instructors' control.

3. Even students with two business majors present differences in learning behavior and communication preference, not to mention other majors and schools. The implementation and evaluation of any policy shall be in line with local conditions.

\section{References}

1. A. Chickering, Z. Gamson Seven Principles for Good Practice in Undergraduate Education. AAHE Bulletin, 39. 3 (1986)

2. D. Cole, Do Interracial Interactions Matter? An Examination of Student Faculty Contact and Intellectual Self-Concept. Journal of Higher Education, 78. 249 (2007)

3. S. Hurtado, K. Eagan, M. Tran, C. Newman, M. Chang, P. Velasco We Do Science Here: Underrepresented Students' Interactions with Faculty in Different Contexts. Journal of Social Issues. 67. 3. 553 (2011)

4. Enqiang Hong, Hu Tianyou A Case Study of Solutions to Problems in Practicing Office Hours System in Mainland Universities of China. Journal of Ningbo University(Educational Science Edition), 34. 05. 59 (201 2)

5. L. Li, J. Pitts Does It Really Matter? Using Virtual Office Hours to Enhance StudentFaculty Interaction. Journal of Information Systems Education, 20, 2. 175 (2009) 
6. S. L. Dika Relations with faculty as social capital for college students: Evidence from Puerto Rico. Journal of College Student Development. 53.596 (2012)

7. L. Layne Defining effective teaching. Journal on Excellence in College Teaching, 23. 1. 43 (2012)

8. Whitney Griffin Starting the Conversation: An Exploratory Study of Factors That Influence Student Office Hour Use. College Teaching. 62. 3.94 (2014)

9. Margaret Smith Office Hours Are Kind of Weird': Reclaiming a Resource to Foster Student-Faculty Interaction. InSight: A Journal of Scholarly Teaching. 12. 14 (2017)

10. O.Cifuentes, N. Lents Increasing Student-Teacher Interactions at an Urban Commuter Campus through Instant Messaging and Online Office Hours. Electronic Journal of Science Education. 14. 1.1 (2010)

11. S.Cotten, B. Wilson Student Faculty Interactions: Dynamics and Determinants. Higher Education. 51. 487 (2006)

12. Jianping Luo, Luting Ma On the Relationship between Students' Type and Learning Behaviors. Journal of National Academy of Education Administration. 08.78 (2013) 